\title{
Analysis of Water Quality Based on Physical and Chemical Data in Hanjiang River Basin (China)
}

\author{
Hong-wei WANG ${ }^{1,2, ~ a}$, Wen-bo ZHAO ${ }^{1, b}$, Chun-long $\mathrm{ZHAO}^{3, \mathrm{c}}{ }^{*}$, \\ Rong ZHENG ${ }^{4, d}$, Zhao-jin CUI ${ }^{5, \mathrm{e}}$, Xing WANG ${ }^{1, f}$, Ya-xin WANG ${ }^{1, g}$, \\ Xia-xia ZHANG ${ }^{1, h}$, Ruo-xi SHI ${ }^{1, i}$
}

1. The Key Laboratory of Zoological Systematics and Application, College of Life Sciences, Hebei University, Baoding, Hebei 071002, P.R. China

2. Laboratory of Environmental Toxicology and Aquatic Ecology, Ghent University , Ghent , Belgium

3. Marine Living Resources and Environment Key Laboratory of Hebei Province, Qinhuangdao , P.R .China

${ }^{4}$ Institute of Supervision and Inspection of Quality and Technology, Shanghai, P.R .China

5. Hebei Ocean \& Fishery Sciences Research Institute , Qinhuangdao , P.R .China awanghw6688@gmail.com, bhwoods@126.com, c906472733@qq.com (*Corresponding author), d13323249639@163.com, eok200090@hotmail.com , f2891285682@qq.com, gbio2008@126.com,h511898215@qq.com,ihydro6688@163.com

Keywords: Physical and Chemical Data; Water Quality; Hanjiang River; Basin

Abstract. According to the investigation of 25 stations in Hanjiang River Basin in August 2015 and January 2016, the aquatic health index of the region was evaluated by using the evaluation method. The diversity evaluation grade was light or non-polluting in August 2015 while diversity rating for the heavy pollution in January 2016. Water quality in the summer is better than that in winter season. The greater impact of plankton water quality factor for the total nitrogen and total phosphorus. water ecology evaluation results can better reflect Eutrophication and the degree of risk of algal blooms such as aquatic in water of Hanjiang River Basin.

\section{Introduction}

Meijiang River Basin and Tingjiang River Basin is the main part of Hanjiang River source, which is in Guangdong province, China. This study provides the basis for ecological protection and management in Hanjiang River Basin.

\section{Materials and methods}

\section{Introduction of Sampling Basin}

The sampling site is located in the Hanjiang River Basin including dry river basin, a reservoir basin, the Yongding River Basin, Zhang Xi River Basin, Mianhuatan Basin, the survey conducted two phases, Respectively August 2015 wet season and dry season in January 2016, Simultaneous detection of water quality data and aquatic data.

\section{Physical and Chemical Data Analysis of Sampling Basin}

Analysis on monitoring data of water quality results in dry and wet season:

The target water quality of single factor water quality evaluation is three kinds of standard of surface water, the single factor water quality evaluation of water quality of Hanjiang River Basin show 
that the water quality of Hanjiang River Basin is inferior to five, part of the basin into four categories, the main pollutant of total phosphorus, total nitrogen, the Hanjiang River Basin were chlorophylla, total phosphorus, total nitrogen, permanganate index evaluation comprehensive nutrition state for water quality comprehensive nutrition state of mild eutrophication ${ }^{[1]}$.

\section{Single factor evaluation}

Calculation method of single factor pollution index of water quality: $\mathrm{pH}$ and $\mathrm{DO}$ use a separate evaluation method, the remaining indicators using a general method ${ }^{[2]}$.

\section{Evaluation results}

Using the formula of single factor pollution index, according to the 2015-2016 River Basin in Changtan reservoir, Duobao reservoir, Mianhuatan reservoir water quality monitoring of the 25 monitoring sections of value calculated each section of water quality index $\mathrm{Pi}$ value, according to the Pi value and water quality requirements, the evaluation results of the water quality section are obtained, determine the main pollution indicators at the same time, should be marked multiples of this index concentration than Class III water quality standards in the index, which exceed the standard ratio for water temperature, $\mathrm{pH}$ value and dissolved oxygen and other projects do not exceed the standard calculation of multiples ${ }^{[3]}$.

\section{Comprehensive evaluation method of water quality}

The nutritional status of water quality was evaluated by the method of comprehensive nutrition state index ${ }^{[4]}$, The correlation between Chla of Chinese lakes (reservoirs) and other parameters $\mathrm{r}_{\mathrm{ij}}$ and $\mathrm{r}_{\mathrm{ij}}^{2}$ are shown in Table:

Table 1 Correlation between some parameters of Chinese lakes (reservoirs) and Chla $\mathrm{r}_{\mathrm{ij}} \mathrm{and} \mathrm{r}_{\mathrm{ij}}{ }^{2}$

\begin{tabular}{llllll}
\hline parameter & chla & TP & TN & SD & COD $_{\text {Mn }}$ \\
\hline $\mathrm{r}_{\mathrm{ij}}{ }^{2}$ & 1 & 0.84 & 0.82 & -0.83 & 0.83 \\
$\mathrm{r}_{\mathrm{ij}}{ }^{2}$ & 1 & 0.7056 & 0.6724 & 0.6889 & 0.6889 \\
\hline
\end{tabular}

Under the same nutritional status, the higher the index value is, the higher the nutritional level is.In this evaluation, Chlorophyll a (Chla), total phosphorus (TP), total nitrogen (TN), permanganate index (CODMn) four index were chosen to evaluate. 


\section{Evaluation results of water nutritional status quality}

Table 2 Comprehensive evaluation of water quality in Meizhou during 2015-2016

\begin{tabular}{|c|c|c|c|c|c|}
\hline $\begin{array}{l}\text { Sample } \\
\text { number in } \\
\text { January }\end{array}$ & Index (opacity) & Afterinspection & $\begin{array}{l}\text { Sample } \\
\text { number in } \\
\text { August }\end{array}$ & Index & Afterinspection \\
\hline 1 & 39.97 & Mesotropher & 1 & 58.15 & light eutropher \\
\hline 2 & 53.51 & light eutropher & 2 & 53.12 & light eutropher \\
\hline 3 & 46.10 & Mesotropher & 3 & 55.77 & light eutropher \\
\hline 4 & 47.37 & Mesotropher & 4 & 52.19 & light eutropher \\
\hline 5 & 46.80 & Mesotropher & 5 & 47.57 & Mesotropher \\
\hline 6 & 40.36 & Mesotropher & 6 & 48.92 & Mesotropher \\
\hline 7 & 40.20 & Mesotropher & 7 & 42.82 & Mesotropher \\
\hline 8 & 40.17 & Mesotropher & 8 & 49.45 & Mesotropher \\
\hline \multirow[t]{2}{*}{9} & \multirow[t]{2}{*}{65.20} & \multirow[t]{2}{*}{$\begin{array}{l}\text { Middle } \\
\text { eutropher }\end{array}$} & 9 & 60.86 & $\begin{array}{l}\text { Middle } \\
\text { eutropher }\end{array}$ \\
\hline & & & 10 & 59.11 & light eutropher \\
\hline 11 & 73.04 & $\begin{array}{l}\text { Hyper } \\
\text { eutropher }\end{array}$ & 11 & 60.81 & $\begin{array}{l}\text { Middle } \\
\text { eutropher }\end{array}$ \\
\hline 12 & 64.15 & $\begin{array}{l}\text { Middle } \\
\text { eutropher }\end{array}$ & 12 & 63.29 & $\begin{array}{l}\text { Middle } \\
\text { eutropher }\end{array}$ \\
\hline 13 & 62.89 & $\begin{array}{l}\text { Middle } \\
\text { eutropher }\end{array}$ & 13 & 63.90 & $\begin{array}{l}\text { Middle } \\
\text { eutropher }\end{array}$ \\
\hline 14 & 54.56 & light eutropher & 14 & 55.74 & light eutropher \\
\hline 15 & 41.55 & Mesotropher & 15 & 48.78 & Mesotropher \\
\hline 16 & 39.62 & Mesotropher & 16 & 37.82 & Mesotropher \\
\hline 17 & 40.11 & Mesotropher & 17 & 40.94 & Mesotropher \\
\hline 18 & 39.50 & Mesotropher & 18 & 38.43 & Mesotropher \\
\hline 19 & 40.50 & Mesotropher & & & \\
\hline 20 & 37.24 & Mesotropher & 20 & 36.99 & Mesotropher \\
\hline 21 & 37.82 & Mesotropher & 21 & 40.84 & Mesotropher \\
\hline 22 & 44.35 & Mesotropher & 22 & 41.42 & Mesotropher \\
\hline 23 & 51.80 & light eutropher & 23 & 55.72 & light eutropher \\
\hline 24 & 52.84 & light eutropher & 24 & 52.15 & light eutropher \\
\hline 25 & 58.20 & light eutropher & 25 & 59.68 & light eutropher \\
\hline
\end{tabular}

Evaluation results of water nutritional status quality

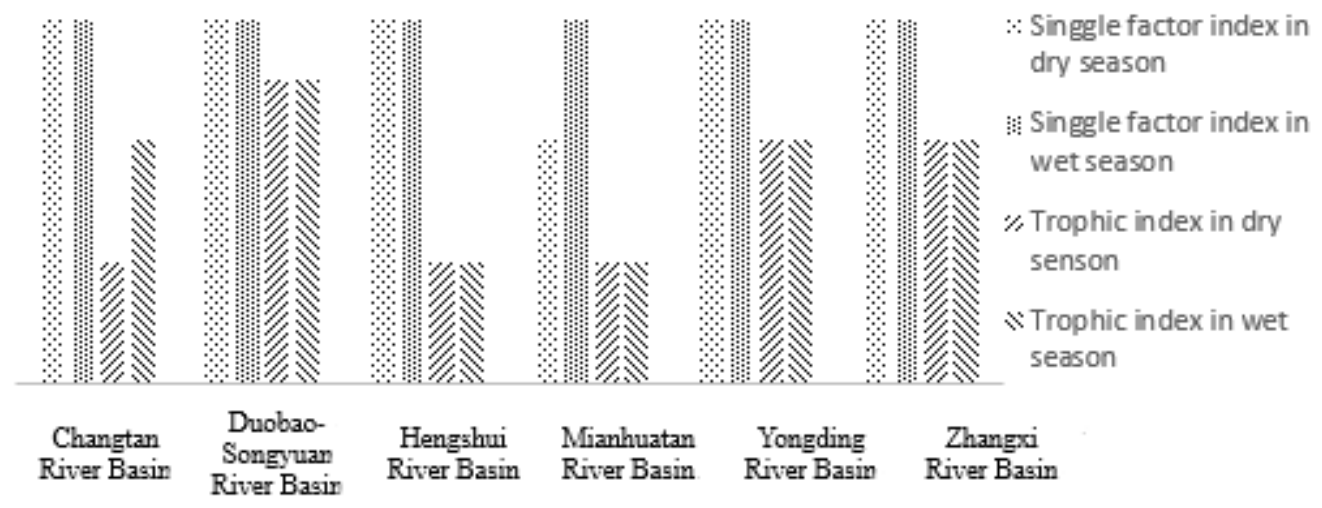

Fig.1 The comparison in Dry and wet period in different water quality and nutritional status of single factor in Hanjiang River Basin 


\section{Conclusion}

On the mutagenicity and the plentiful water quality monitoring data analysis results are as follows: The evaluation of single factor water quality in Hanjiang River Basin shows that the water quality in Hanjiang River Basin was integrated to five classes ${ }^{[5]}$, part of the basin to four categories, main pollutants for total phosphorus, total nitrogen, chlorophyll a and total phosphorus, total nitrogen.

\section{Acknowledgements}

We wish to thank Prof. Zhi-ping MEI, Dr. Zhen-yu ZHANG and Dr. Yi-feng DU for editing this manuscript. We are grateful for the constructive comments of the reviewers. This research was supported by the Subject of advantage characteristic biology in Hebei Province ; The natural science foundation of Hebei Province ( D2013201105 ) ; Students studying abroad preferred activities of science and technology project funding projects in hebei province ( C2015003034) ; The Project-sponsored by SRF for ROCS , SEM(2014); Hydrobiology key discipline in Hebei province ; Modern Agriculture Industry Technology System Characteristic Seafood Innovation Team in Hebei Province ( 2013-2017) ; Projects of coastal habitat restoration in Qinhuangdao (Provincial Science and Technology Department, No. 15273303D) ; Hebei Provincial Key Laboratory of operating subsidy (item number: 14967611D) ; National Innovation Innovation Training Program, Hebei University (201610075014); Graduate Student Innovation Fund Project, Hebei University (X2016072); Field Innovation Entrepreneurship Training Program, Hebei University (2016084); Laboratory Open Project, Hebei University (sy201662).

\section{References}

[1] PRADHAN U K,SHIRODKAR P V,SAHU B K. Physico-chemical characteristicsof the coastal water off Dev i estuary, Orissa and evaluation of its seasonal changes using chemometric techniques[J]. Current Science,200 9, 96(9):1203-1209.

[2] EL-OTIFY A M,ISKAROS I A. Water quality and potamoplankton evaluation of the Nile River in Upper Egy pt[J]. Acta Limnologica Brasiliensia, 2015, 27(2):171-190.

[3] KOKLU R,SENGORUR B,TOPAL B. Water Quality Assessment Using Multivariate Statistical Methods-A Case Study: Melen River System (Turkey)[J]. Water Resources Management, 2010, 24(5):959-978.

[4] OLGUIN H F,PUIG A,LOEZ C R,et al. An integration of water physicochemistry, algal bioassays, phytoplank ton, and zooplankton for ecotoxicological assessment in a highly polluted lowland river [J]. Water Air and Soil Pollution, 2004, 155(1-4):355-381.

[5] SAPPA G,ERGUL S,FERRANTI F,et al. Effects of seasonal change and seawater intrusion on water quality $\mathrm{f}$ or drinking and irrigation purposes, in coastal aquifers of Dar es Salaam, Tanzania [J]. Journal of African Earth Sciences, 2015,105:64-84. 